\title{
Faktor-Faktor yang Memengaruhi Indeks Pembangunan Manusia di Provinsi Kalimantan Tengah
}

\author{
Latif Arafat $^{1 *}$, Wiwiek Rindayati ${ }^{2}$, Sahara $^{2}$ \\ ${ }^{1}$ BPS Kabupaten Pulang Pisau \\ ${ }^{2}$ Departemen Ilmu Ekonomi \\ Fakultas Ekonomi dan Manajemen, Institut Pertanian Bogor \\ "Korespondensi: latif.arafat@gmail.com
}

[diterima: September 2018- revisi: Oktober 2018-diterbitkan daring: Desember 2018]

\begin{abstract}
ABSTRAK
Selama tahun 2010-2015 peringkat Indeks Pembangunan Manusia (IPM) Provinsi Kalimantan Tengah mengalami penurunan. Peringkat IPM juga relatif rendah dibanding indikator lain seperti kemiskinan, pengangguran dan rasio gini. Penelitian ini bertujuan untuk mendeskripsikan kinerja IPM dan faktorfaktor yang memengaruhi IPM pada kabupaten/kota di Kalimantan Tengah. Metode yang digunakan adalah regresi data panel 14 kabupaten/kota di Kalimantan Tengah tahun 2010-2015. Berdasarkan hasil penelitian, kabupaten seruyan dan pulang pisau memiliki nilai dan laju pertumbuhan IPM yang rendah. Indeks rata-rata lama sekolah merupakan indeks terendah dalam penyusunan IPM di Kalimantan Tengah, sehingga menjadi beban karena penghitungan metode baru menggunakan rata-rata geometri. Hasil model menunjukan bahwa PDRB perkapita, alokasi APBD untuk kesehatan, tingkat pengangguran, dan dummy kota kabupaten berpengaruh positif sedangkan kemiskinan dan rasio ketergantungan berpengaruh negatif terhadap IPM. Variabel yang memiliki pengaruh terbesar terhadap nilai IPM adalah PDRB perkapita. Saran yang diberikan untuk menaikkan PDRB adalah pengembangan kluster industri kelapa sawit di Provinsi Kalimantan Tengah.
\end{abstract}

Kata kunci: data panel, Indeks Pembangunan Manusia (IPM), Kalimantan Tengah

\begin{abstract}
During the years between 2010 and 2015, Central Kalimantan's Human Development Index (HDI) rank has decreased. Its HDI rank is also relatively low if compared to other indicators such as poverty, unemployment, and the gini ratio. This study aims to describe the HDI performance and the factors affecting HDI in regencies / cities in Central Kalimantan. The method used is the panel data regression of 14 regencies / cities in Central Kalimantan from 2010 to 2015. Based on the study results, Seruyan Regency and Pulang Pisau Regency has a low value and growth of HDI. The mean years of schooling index is the lowest index of the HDI components in Central Kalimantan, thus becoming a burden since the new calculation method is using the geometry average. The model results showed that GDP per capita, budgetary allocation for the health, unemployment rate, and dummy regencies / cities have positive effect, while poverty and dependency ratio have negative effect on HDI. The variable that have the greatest influence on the HDI value is GDP per capita. Therefore, the suggested recommendation is to increase GDP by the means of the development of palm oil cluster in Central Kalimantan.
\end{abstract}

Keywords: Central Kalimantan, Human Development Index (HDI), Panel Data.

JEL code: 015 . E24 


\section{PENDAHULUAN}

Sebelum tahun 1970-an pembangunan dianggap sebagai fenomena ekonomi biasa. Pembangunan hanya diukur dengan pertumbuhan produk domestik bruto (PDB). Suatu negara yang memiliki pertumbuhan PDB tinggi akan menjadi sejahtera. Hal ini karena anggapan bahwa dengan pertumbuhan PDB tinggi akan menetes dengan sendirinya ke variabel ekonomi yang lain seperti penciptaan lapangan pekerjaan, kemiskinan, dan ketimpangan. Selain pembangunan ekonomi, pembangunan manusia juga semakin menjadi sorotan.

Manusia adalah kekayaan bangsa yang sesungguhnya. Tujuan utama dari pembangunan adalah menciptakan lingkungan yang memungkinkan bagi rakyatnya untuk menikmati umur panjang, sehat dan menjalankan kehidupan yang produktif (UNDP dalam BPS, 2015). Pembangunan manusia merupakan paradigma pembangunan dimana manusia ditempatkan sebagai subjek kegiatan ekonomi. Fokus dan sasaran pembangunan yaitu tercapainya penguasaan atas sumber daya manusia guna memperoleh pendapatan untuk mencapai hidup yang layak agar dapat memengaruhi pertumbuhan ekonomi. Pembangunan manusia menjadi tujuan akhir segala macam pembangunan.

Salah satu indikator yang digunakan untuk mengukur pembangunan manusia adalah Indeks Pembangunan Manusia (IPM). IPM merupakan indeks komposit yang diukur melalui tingkat pendidikan, kesehatan dan pendapatan. IPM pertama kali diperkenalkan oleh United Nations Development Program (UNDP) pada tahun 1990 melalui publikasi Human Development Report 1990. Dalam penghitungan IPM, digunakan tiga dimensi yaitu umur panjang dan hidup sehat, pengetahuan, dan standar hidup layak. Dari ketiga dimensi tersebut diturunkan menjadi empat indikator yaitu harapan hidup saat lahir, rata-rata lama sekolah, harapan lama sekolah, dan produk nasional bruto (PNB) perkapita.

Nilai IPM di Indonesia tahun 2015 sebesar 69.55. Nilai tersebut selalu meningkat dari tahun 2010 yang bernilai 66.53. Meski setiap tahun nilai
IPM selalu naik, tetapi dari publikasi UNDP tahun 2015 disebutkan peringkat IPM Indonesia tahun 2014 berada di posisi ke-110 dari 188 negara yang menghitung IPM. Peringkat IPM Indonesia berada jauh di bawah negara tetangga di kawasan ASEAN yaitu Singapura (91.2), Brunei Darussalam (85.6), Malaysia (77.9), dan Thailand (72.6).

Kalimantan Tengah merupakan salah satu provinsi yang ada di Indonesia dengan tren nilai IPM sama seperti IPM nasional. Tren IPM Kalimantan Tengah selalu meningkat, tetapi peringkatnya mengalami penurunan apabila dibandingkan dengan provinsi lain. Tahun 2010 nilai IPM Kalimantan Tengah sebesar 65.96 dan selalu meningkat tiap tahun hingga pada tahun 2015 sebesar 68.53. Peringkat IPM Kalimantan Tengah tahun 2010 adalah 17 dari 33 Provinsi di Indonesia dan tahun 2015 peringkatnya menurun menjadi 21 dari 34 provinsi.

Kondisi IPM di Kalimantan Tengah secara kewilayahan/spasial menunjukan kondisi yang timpang. Nilai IPM Kota Palangka Raya jauh di atas wilayah lain di Provinsi Kalimantan Tengah. Terjadi perbedaan kualitas pembangunan manusia yang mencolok antar kabupaten/kota. Kota Palangka Raya terlihat sangat berbeda kualitas pembangunan manusianya dibandingkan dengan wilayah lain di Kalimantan Tengah.

Penelitian terdahulu masih menggunakan data IPM dengan metode penghitungan deret aritmatik dan indikator penyusun dengan angka melek huruf dan PDB perkapita. Metode tersebut dianggap tidak relevan sehingga UNDP telah menyempurnakan metode tersebut dan sudah diadopsi oleh BPS mulai tahun 2015. Penelitian ini menggunakan data IPM dengan metode penghitungan yang baru. Nilai IPM Kota Palangka Raya terlihat jauh lebih tinggi dari nilai IPM kabupaten. Penelitian ini menggunakan variabel dummy kota dan kabupaten untuk melihat apakah ada perbedaan nyata antara wilayah kabupaten dan kota.

Berdasarkan uraian sebelumnya maka tujuan penelitian adalah (1) Mendeskripsikan kinerja IPM di Provinsi Kalimantan Tengah. (2) Menganalisis 
faktor-faktor yang memengaruhi IPM kabupaten/ kota di Provinsi Kalimantan Tengah.

\section{TINJAUAN PUSTAKA \\ Pembangunan Manusia}

Pembangunan manusia memiliki makna yang sangat luas. Tujuan utama pembangunan harus menciptakan lingkungan yang memungkinkan untuk menikmati umur panjang, sehat, dan menjalankan kehidupan dengan produktif (UNDP, 1990). Pembangunan dan pembangunan manusia memiliki perbedaan. Pembangunan lebih menekankan ke pertumbuhan ekonomi, pembentukan modal manusia, sumber daya manusia, kesejahteraan rakyat, dan pemenuhan kebutuhan dasar. Pembangunan manusia fokus ke perluasan pilihan hidup masyarakat agar mendapatkan hidup yang bebas dan bermartabat. Pembangunan manusia memandang dengan pendekatan yang lebih komprehensif dari sudut pandang manusia pada sektor pertumbuhan ekonomi, perdagangan, ketenagakerjaan, kebebasan politik maupun nilai-nilai kultural (BPS, 2015).

Memiliki umur panjang dan hidup sehat, mendapat pendidikan, dan memiliki akses terhadap kebutuhan hidup layak merupakan level pembangunan yang paling mendasar. Apabila pilihan mendasar tersebut tidak tersedia, maka pilihan lain tidak dapat diakses (UNDP, 1990). Pembangunan manusia tidak terbatas pada kebutuhan dasar diatas, tetapi lebih dari itu yaitu politik, kebebasan untuk memiliki peluang dalam kegiatan ekonomi dan sosial, serta harga diri dan jaminan hak asasi manusia. Tapi pilihan tersebut tidak dapat dimiliki apabila kebutuhan dasar tidak dimiliki. Tidak mungkin seseorang memiliki kebebasan dalam kegiatan ekonomi apabila sakit ataupun tidak memiliki pendidikan yang layak.

Pembangunan harus fokus pada manusia. Pembangunan bukan hanya nilai pertumbuhan ekonomi tetapi pembangunan adalah pembangunan manusia itu sendiri. Pembangunan yang disertai perluasan pilihan bagi masyarakatnya untuk menjadi lebih bermartabat dan perluasan kapabilitas untuk memenuhi aspirasinya.
Pembangunan manusia merupakan tujuan akhir dari segala macam pembangunan.

\section{Indeks Pembangunan Manusia}

Indeks pembangunan manusia pertama kali diperkenalkan oleh United Nation Development Program (UNDP) pada tahun 1990. Indeks pembangunan manusia merupakan indeks komposit dari tiga dimensi yaitu umur panjang dan hidup sehat, pengetahuan, dan standar hidup layak. Dari tiga dimensi tersebut diturunkan menjadi empat indikator yaitu angka harapan hidup saat lahir (AHH) untuk mengukur dimensi umur panjang dan hidup sehat, rata-rata lama sekolah dan harapan lama sekolah untuk mengukur dimensi pengetahuan, dan produk nasional bruto (PNB) perkapita untuk mengukur dimensi standar hidup layak. Secara berkala UNDP melakukan penyempurnaan metodologi baik dari indikator maupun cara penghitungan. Empat indikator yang disebutkan diatas telah mengalami perubahan dari awal diperkenalkan. Empat indikator saat awal diperkenalkan yaitu angka harapan hidup saat lahir, angka melek huruf (AMH), angka partisipasi kasar (APK), dan produk domestik bruto (PDB) perkapita. Selain itu cara hitung IPM juga mengalami perubahan, dari rata-rata aritmatik menjadi rata-rata geometrik.

Nilai IPM berkisar antara 0-100. Apabila nilai IPM semakin dekat dengan 100, semakin bagus pembangunan manusia di wilayah tersebut. Penghitungan IPM hanya mencakup tiga komponen utama, sehingga kita harus melihat IPM sebagai penyederhanaan realitas yang kompleks dari luasnya definisi dan dimensi pembangunan manusia.

\section{Kompenen-komponen IPM Angka Harapan Hidup saat Lahir}

Angka harapan hidup saat lahir (AHH) adalah rata-rata banyaknya tahun seseorang untuk dapat hidup dari lahir sampai mati. Angka harapan hidup dihitung dengan pendekatan tak langsung karena sulitnya mengikuti data kematian setiap tahunnya dari suatu kohor. Data yang digunakan dalam penghitungan $\mathrm{AHH}$ adalah data Anak Lahir Hidup (ALH) dan Anak masih hidup (AMH) 
menggunakan paket program pemrograman Mortpack.

Indeks harapan hidup dihitung dengan rumus yang dikembangkan oleh UNDP, yaitu membandingkan dengan nilai maksi-mum dan nilai minimum harapan hidup. Angka maksimum untuk penghitungan indeks harapan hidup adalah 85 tahun dan terendah 20 tahun.

\section{Tingkat Pendidikan}

Tingkat pendidikan diwakili oleh dua indikator yaitu rata-rata lama sekolah (mean years of schooling) dan harapan lama sekolah (expected years of schooling). Untuk menyusun indeks pendidikan, rata-rata lama sekolah dan harapan lama sekolah dijumlahkan dan dibagi dua. Ratarata lama sekolah dan harapan lama sekolah memiliki bobot yang sama dalam menyusun indeks pendidikan sebagai salah satu dimensi penyusunan IPM.

Rata-rata lama sekolah adalah rata-rata jumlah tahun yang digunakan penduduk usia 25 tahun keatas dalam menjalani pendidikan formal. Penghitungan rata-rata lama sekolah menggunakan batasan dari UNDP yaitu maksimal 15 tahun dan minimal 0 tahun.

Harapan lama sekolah adalah rata-rata jumlah tahun lamanya bersekolah yang diharapkan akan dirasakan oleh anak pada umur 7 tahun. Indikator ini digunakan untuk mengetahui kondisi pembangunan pendidikan diberbagai jenjang dan diharapkan dapat dicapai oleh setiap anak. Batasan yang digunakan adalah maksimal 18 tahun dan minimal 0 tahun.

\section{Standar Hidup Layak}

Standar hidup layak menggambarkan tingkat kesejahteraan yang dinikmati oleh penduduk sebagai dampak semakin membaiknya ekonomi (BPS 2016). Ada perbedaan perhitungan standar hidup layak antara UNDP dan BPS. Perbedaan ini dilakukan sesuai dengan ketersediaan data untuk membandingkan antara wilayah di Indonesia. UNDP menggunakan Produk Nasional Bruto (PNB) perkapita yang disesuaikan, sedangkan BPS menghitung standar hidup layak menggunakan rata-rata pengeluaran perkapita riil yang disesuaikan dengan paritas daya beli (purchasing power parity). Data PNB di Indonesia tidak tersedia sampai level provinsi/kabupaten/ kota sedangkan pengeluaran riil bisa didapatkan dari hasil Survei Sosial Ekonomi Nasional (Susenas) yang tersedia sampai level kabupaten/kota. Penghitungan paritas daya beli dilakukan berdasarkan 96 komoditas kebutuhan pokok. Batasan yang digunakan dalam penghitungan indeks pengeluaran adalah maksimal Rp 26572 353.- dan batas minimal Rp 1007 436.-

Pengitungan komponen IPM berdasarkan rumus sebagai berikut:

$$
\begin{aligned}
& \mathrm{I}_{\mathrm{AHH}}=\frac{\mathrm{AHH}-\mathrm{AHH}_{\min }}{\mathrm{AHH}_{\max }-\mathrm{AHH}_{\min }} \\
& \mathrm{I}_{\mathrm{HLS}}=\frac{\mathrm{HLS}^{\mathrm{HLS}}}{\mathrm{HLS}_{\max }} \\
& I_{R L S}=\frac{R_{L S}-R L S_{\min }}{R L S_{\max }-R S_{\min }} \\
& \mathrm{I}_{\text {pengetahuan }}=\frac{\mathrm{I}_{\mathrm{HLS}}-\mathrm{I}_{\mathrm{RLS}}}{2} \\
& I_{\text {pengeluaran }}=\frac{\ln (\text { pengeluaran })-\ln \left(\text { pengeluaran }_{\text {min }}\right)}{\ln \left(\text { pengeluaran }_{\max }\right)-\ln \left(\text { pengeluaran }_{\min }\right)}
\end{aligned}
$$

Penghitungan nilai IPM menggunakan rumus sebagai berikut:

$\mathrm{IPM}=\sqrt[3]{\mathrm{I}_{\text {kesehatan }} \times \mathrm{I}_{\text {pendidikan }} \times \mathrm{I}_{\text {pengeluaran }}}$

Pengelompokan IPM menjadi empat kelompok untuk mengorganisasikan wilayah-wilayah menjadi kelompok yang sama dalam hal pembangunan manusia. Berikut pembagian kelompok nilai IPM

1. Kelompok sangat tinggi: IPM $\geq 80$

2. Kelompok tinggi: $70 \leq \mathrm{IPM}<80$

3. Kelompok sedang: $60 \leq \mathrm{IPM}<70$

4. Kelompok rendah: IPM $<60$

Dalam penghitungan IPM metode baru dengan geometrik, tidak dikenal lagi istilah reduksi shortfall, tetapi sudah diganti dengan pertumbuhan 
IPM. Pertumbuhan IPM untuk mengukur perkembangan nilai IPM dalam kurun waktu tertentu. Semakin tinggi pertumbuhan IPM, semakin cepat peningkatan nilai IPM. Penghitungan pertumbuhan IPM menggunakan rumus seperti dibawah ini:

Pertumbuhan IPM $=\frac{\mathrm{IPM}_{\mathrm{t}}-\mathrm{IPM}_{\mathrm{t}-1}}{\mathrm{IPM}_{\mathrm{t}-1}} \times 100 \%$

\section{Perubahan Metodologi IPM}

Suatu indeks komposit harus mampu mengukur apa yang diukur. Ada dua alasan utama perubaan metodologi IPM (BPS 2015). Pertama, terdapat indikator sudah tidak relevan dalam. Indikator tersebut adalah angka melek huruf (AMH) dan PDB perkapita. AMH dianggap tidak lagi relevan dalam mengukur pendidikan secara utuh karena tidak menggambarkan kualitas pendidikan. PDB perkapita pada dasarnya merupakan proksi pendapatan masyarakat, namun PDB diciptakan dari seluruh faktor produksi dan ada investasi asing yang turut diperhitungkan. Oleh karena itu PDB per kapita dianggap kurang tepat menggambarkan pendapatan masyarakat. Kedua, penggunaan rumus aritmatik menggambarkan capaian yang rendah di suatu dimensi dapat ditutupi oleh capaian tinggi dari dimensi lain. Konsep yang diusung dalam pembangunan manusia adalah pemerataan pembangunan. Rata-rata aritmatik memungkinkan adanya transfer capaian dari dimensi dengan capaian tinggi ke dimensi dengan capaian rendah (BPS 2015).

Dampak langsung perubahan metode penghitungan IPM ada dua dampak. Pertama, terjadi perubahan level IPM yang lebih rendah dibanding metode lama. Perubahan AMH menjadi HLS membuat IPM lebih rendah karena secara umum AMH sudah diatas 90 persen sementara HLS belum optimal. Perubahan aritmatik menjadi geometrik juga turut andil dalam penurunan level IPM metode baru. Kedua, terjadi perubahan peringkat IPM. Dengan perubahan nilai IPM membuat perubahan peringkat IPM baik dalam tingkat negara, provinsi maupun kabupaten/kota.

\section{Penelitian Terdahulu}

Penelitian mengenai indeks pembangunan manusia telah banyak di teliti di Indonesia baik menggunakan data provinsi maupun kabupaten/kota diantaranya oleh Trunajaya (2015), Sa'diyah (2014), Pratowo (2011), Sofilda et al (2013), Yuliati (2012), dan Hamzah et al (2012). Dari semua penelitian tersebut, belum ada yang melakukan penelitian di Provinsi Kalimantan Tengah walaupun ada permasalahan IPM di daerah tersebut. Penelitian ini mengisi adanya gap penelitian IPM di Provinsi Kalimantan Tengah.

Kemiskinan berpengaruh terhadap IPM berdasarkan penelitan dari Trunajaya (2015), Sofilda et al (2013), dan Yuliati (2012). Menurut Sofilda et al (2013) Pembangunan manusia tidak bisa dipisahkan dengan kemiskinan, jadi apabila ingin membangun manusia maka harus juga diikuti dengan pengentasan kemiskinan karena setiap dimensi IPM adalah pemicu bagi pengentasan kemiskinan. Rasio ketergantungan memiliki pengaruh terhadap IPM berdasarkan penelitian yang dilakukan oleh Pratowo (2011).

APBD tidak signifikan memengaruhi IPM berdasarkan penelitian dari Sa'diyah (2014), berbeda dengan hasil penelitian Sofilda et al (2013). Penelitian ini berusaha membagi APBD menurut fungsinya seperti yang dilakukan oleh Hamzah et al (2012) dan Yuliati (2012). Fungsi APBD yang digunakan dalam penelitian ini berdasarkan fungsi kesehatan dan pendidikan. Pengangguran memiliki pengaruh yang negatif sesuai penelitian yang dilakukan oleh Hamzah dkk (2012).

PDRB perkapita memiliki pengaruh terhadap IPM berdasarkan penelitian terdahulu yang dilakukan oleh Sa'diyah (2014), Yuliati (2012), dan Hamzah et al (2012). Dummy variabel kota dan kabupaten dimasukkan karena adanya level IPM yang berbeda antara wilayah kota dan kabupaten di Provinsi Kalimantan Tengah.

Perbedaan penelitian ini dengan penelitian sebelumnya adalah penelitian ini menggunakan perhitungan IPM metode baru dengan penyempurnaan pada indikator pengetahuan dan 
perubahan metode penghitungan dari aritmatik ke geometrik. Penghitungan metode baru mulai diterapkan oleh BPS pada tahun 2014 dengan melakukan penghitungan mundur dari tahun 2010.

\section{METODE PENELITIAN Jenis dan Sumber Data}

Jenis data yang digunakan dalam penelitian ini adalah data panel yang terdiri dari 14 kabupaten/kota di Provinsi Kalimantan Tengah dari tahun 2010 sampai dengan tahun 2015.
Pemilihan tahun awal di 2010 karena menyesuaikan dengan data PDRB menurut harga konstan yang terbaru adalah dari tahun 2010. Selain itu, penghitungan IPM metode baru yang dihitung Badan Pusat Statistik (BPS) adalah dari tahun 2010. Untuk tahun sebelum itu masih menggunakan IPM metode lama. Tahun akhir 2015 menyesuaikan ketersediaan data di BPS untuk yang terbaru. Data yang digunakan adalah data sekunder yang diperoleh dari BPS.

\section{Metode Analisis}

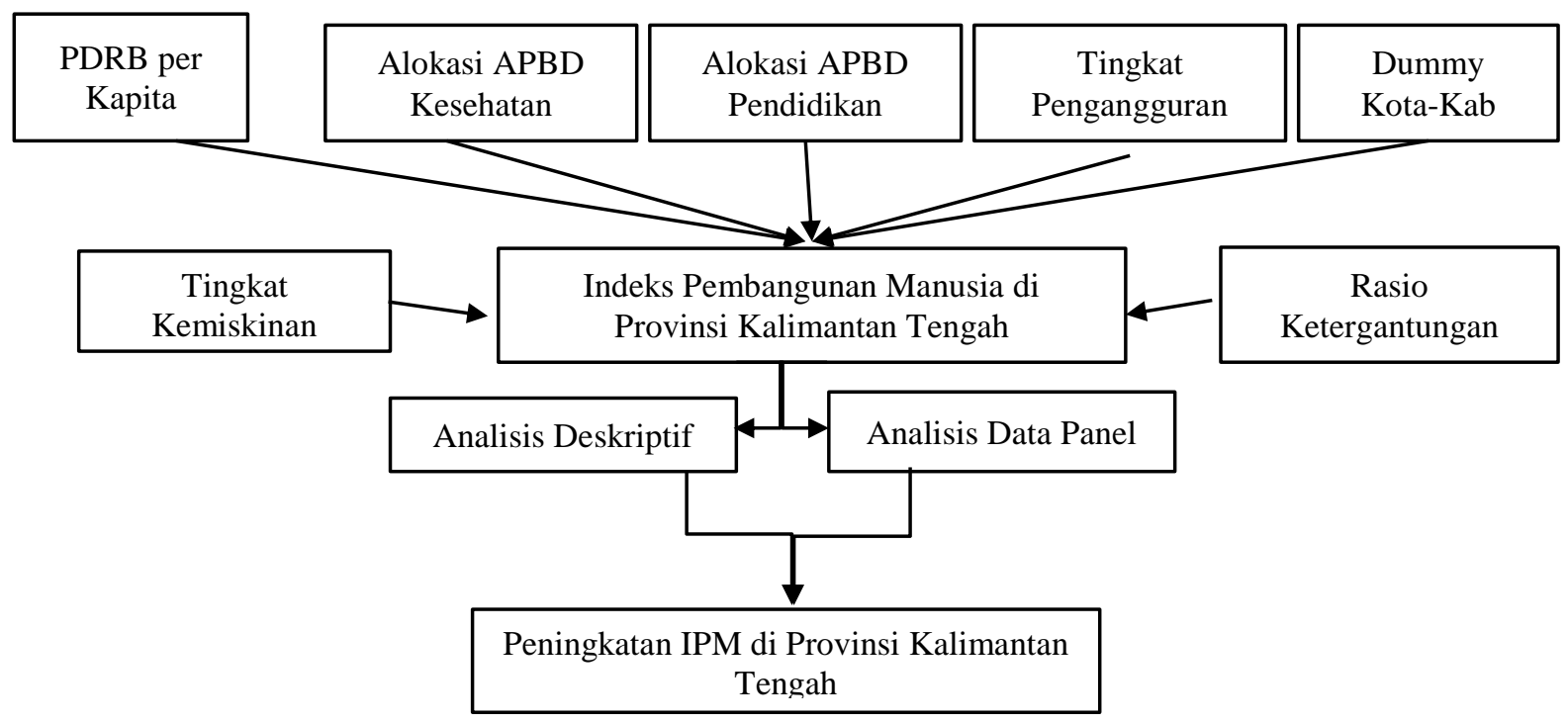

Gambar 1. Kerangka pemikiran

Metode analisis yang digunakan dalam penelitian ini menggunakan analisis deskriptif dan analisis inferensia ekonometrika menggunakan metode data panel. Metode deskriptif digunakan untuk mendeskripsikan hasil Indeks Pembangunan Manusia Provinsi Kalimantan Tengah dan bagaimana posisinya jika dibandingkan dengan IPM Nasional. Analisis deskriptif dilakukan menggunakan tabel dan grafik untuk melihat perkembangan IPM dan dimensinya yang digunakan dalam penelitian ini.

Data panel merupakan gabungan data cross section dan time series. Dalam penggunaan data panel, mengakibatkan kesulitan dalam spesifikasi model karena residual memiliki tiga kemungkinan yaitu residu time series, residu cross section maupun gabungan keduanya. Untuk mengestimasi regresi data panel dikenal tiga macam model yaitu Pooled Least Square (PLS), model efek tetap (fixed effect model/FEM) dan model efek acak (random effect model/REM). Untuk memilih salah satu dari ketiga model diatas digunakan beberapa uji yaitu uji chow, uji lagrange multiplier (LM) dan uji Hausman. Uji Chow untuk menentukan penggunaan FEM atau PLS, uji LM untuk menentukan penggunaan PLS atau REM dan uji hausman untuk menentukan penggunaan REM atau FEM. Kerangka pemikiran pada penilitian ini adalah sebagai berikut: 


\section{Model Penelitian}

Model yang digunakan pada penelitian ini, secara matematis, dapat dilihat seperti dibawah ini:

$$
\begin{aligned}
\mathrm{IPM}_{\mathrm{it}}= & \beta_{0}+\beta_{1} \text { Miskin }_{\mathrm{it}}+\beta_{2} \ln \text { PDRBKAP }_{\mathrm{it}}+ \\
& \beta_{3} \operatorname{lnSehat}_{\mathrm{it}}+\beta_{4} \text { LnDidik }_{\mathrm{it}}+\beta_{5} \mathrm{DR}_{\mathrm{it}}+ \\
& \beta_{6} \mathrm{TPT}_{\mathrm{it}}+\beta_{7} \text { Dummy }+\varepsilon_{\mathrm{it}} \ldots \ldots \text { (8) }
\end{aligned}
$$

Keterangan:

$\beta_{0} \quad=$ intersep

$\beta_{j} \quad=$ Slope variabel $(\mathrm{j}=1,2, \ldots, 7)$

$t \quad=$ waktu

I $=$ kabupaten $/ \operatorname{kota}(\mathrm{i}=1,2, \ldots, 14)$

$\varepsilon \quad=$ Error

IPM $\quad=$ Indeks pembangunan manusia
Miskin $=$ Tingkat kemiskinan (persen)

PDRBKAP $=$ Pendapatan domestik bruto per kapita (rupiah)

Sehat = Alokasi belanja daerah menurut fungsi kesehatan (rupiah)

Didik $=$ Alokasi belanja daerah menurut fungsi pendidikan (rupiah)

DR $=$ Rasio ketergantungan penduduk (indeks)

TPT $=$ Tingkat pengangguran terbuka (persen)

Dummy = Dummy (0 untuk kabupaten, dan 1 untuk Kota Palangka Raya)

Tabel 1. Nilai dan Pertumbuhan IPM Kalimantan Tengah, 2010-2015

\begin{tabular}{ccccccc}
\hline Tahun & 2010 & 2011 & 2012 & 2013 & 2014 & 2015 \\
\hline IPM Kalteng & 65.96 & 66.38 & 66.66 & 67.41 & 67.77 & 68.53 \\
Pertumbuhan & - & 0.64 & 0.42 & 1.12 & 0.53 & 1.13 \\
\hline
\end{tabular}

Sumber: Badan Pusat Statistik (diolah)

HASIL DAN PEMBAHASAN

\section{Gambaran Umum Indeks Pembangunan Manusia di Provinsi Kalimantan Tengah}

Selama kurun waktu 2010 sampai dengan tahun 2015, IPM di Kalimantan Tengah terus mengalami pertumbuhan positif. Meskipun selalu mengalami pertumbuhan, nilai IPM Kalteng masih tetap pada kategori sedang karena nilainya tetap berkisar antara 60 samapi dengan 70 .
Pertumbuhan IPM Kalimantan Tengah paling tinggi adalah tahun 2015 yaitu sebesar 1.13 persen atau 0.76 poin. Secara rata-rata pertumbuhan IPM Kalimantan Tengah setiap tahunnya sebesar 0.77 persen. Meskipun nilai IPM Kalimantan Tengah selama lima tahun telah naik sebesar 2.57 poin atau 3.90 persen, tetapi kategori IPM Kalimantan Tengah masih berkategori sedang. Jika dilihat dari tiga dimensi pembentuk IPM, Kalimantan Tengah mengalami peningkatan di seluruh dimensi.

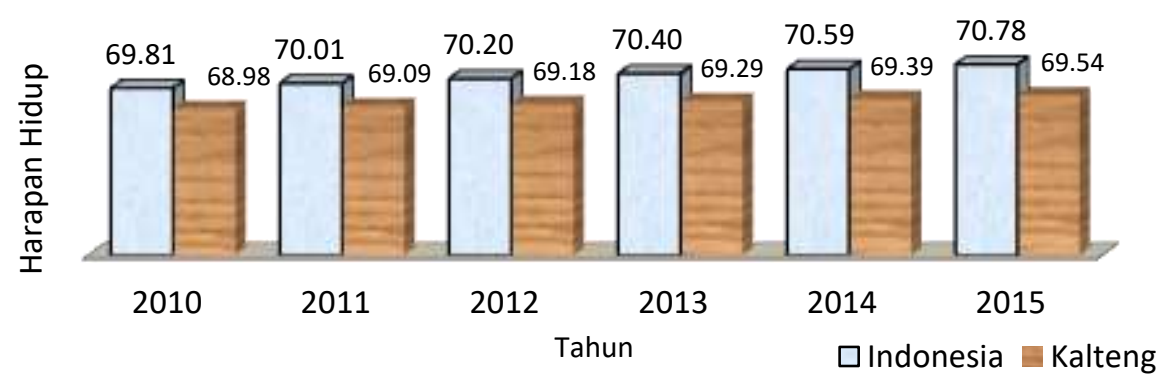

Sumber: Badan Pusat Statistik (diolah)

Gambar 2. Angka Harapan Hidup (AHH) Saat Lahir Kalimantan Tengah dan Indonesia , 2010-2015 


\section{Dimensi Umur Panjang dan Hidup Sehat}

Dimensi umur panjang dan hidup sehat diwakili oleh indikator angka harapan hidup (AHH) saat lahir. Tren angka harapan hidup saat lahir dari tahun 2010 sampai dengan tahun 2015 selalu meningkat baik itu angka nasional maupun Kalimantan Tengah. Hal ini berarti bayi yang baru lahir mempunyai harapan untuk hidup lebih lama karena adanya perbaikan derajat kesehatan suatu wilayah baik dari prasarana, akses, hingga kualitas kesehatan. Hal ini juga disebabkan karena peningkatan sarana dan prasarana kesehatan serta meningkatnya kepedulian masyarakat akan gaya hidup sehat.

Harapan hidup bayi yang baru lahir di Kalimantan Tengah pada tahun 2010 sebesar 68.98 tahun. Harapan hidup ini meningkat setiap tahun hingga sebesar 69.54 tahun di tahun 2015. Berarti dalam waktu 5 tahun harapan hidup bayi baru lahir di Kalimantan Tengah meningkat sebesar 0.56 tahun atau 0.81 persen meningkat 0.16 persen tiap tahun. Harapan hidup bayi baru lahir nasional pada tahun 201069.81 tahun. Harapan hidup tersebut selalu meningkat setiap tahun hingga pada tahun 2015 menjadi 70.78 tahun.

Dari gambar 2 terlihat angka harapan hidup Provinsi Kalimantan Tengah lebih kecil dari harapan hidup nasional. Dengan kata lain penduduk Kalimantan Tengah memiliki peluang umur lebih pendek dari umur penduduk secara Nasional. Menurut data BPS, tahun 2014 terdapat 22.63 persen balita yang lahir dengan penolong kelahiran diluar tenaga medis di Kalimantan Tengah. Angka tersebut berada di bawah angka nasional sebesar 12.91 persen.

\section{Dimensi Pengetahuan}

Dimensi pengetahuan yang digunakan dalam penghitungan IPM adalah agregasi dari angka harapan lama sekolah dan rata-rata lama sekolah. Harapan lama sekolah dan rata-rata lama sekolah Kalimantan Tengah dalam kurun waktu 2010 sampai dengan 2015 selalu mengalami kenaikan. Meskipun demikian, rata-rata lama sekolah relatif lebih lambat pertumbuhannya dibanding harapan lama sekolah. Hal ini karena rata-rata lama sekolah merupakan indikator output pembangunan jangka panjang sedangkan harapan lama sekolah merupakan indikator proses pembangunan program pendidikan jangka pendek. Jadi wajar apabila perkembangan rata-rata lama sekolah relatif lambat. Kedua indikator menggambarkan capaian (stock) dan penambahan (flow) sumber daya manusia disuatu wilayah.

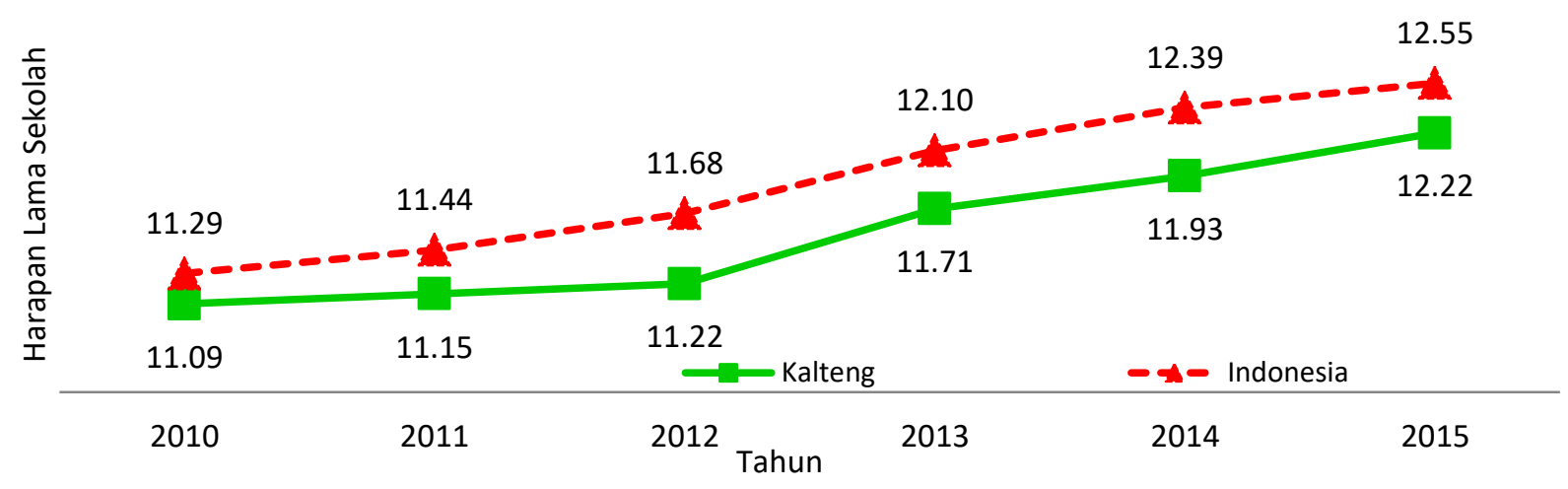

Sumber: Badan Pusat Statistik (diolah)

Gambar 3. Harapan Lama Sekolah Kalimantan Tengah dan Indonesia (Tahun), 2010-2015

Harapan lama sekolah anak usia 7 tahun keatas di Kalimantan Tengah pada tahun 2015 adalah selama 12.22 tahun. Hal tersebut menunjukkan bahwa anak-anak di Kalimantan Tengah memiliki harapan bersekolah telah menamatkan SLTA. Meski demikian harapan untuk menamatkan pendidikan di perguruan tinggi masih rendah, karena hanya 0.22 tahun saja di perguruan tinggi.

Pertumbuhan harapan lama sekolah di Kalimantan Tengah selama periode 2010 sampai dengan 2015 adalah 1.13 tahun (10.19 persen) atau 2.04 persen setiap tahun. Meskipun setiap tahun 
dari 2010 selalu ada kenaikan, tapi kenaikan tersebut lebih lambat dari Nasional, terlihat pada Gambar 3. Harapan lama sekolah anak usia 7 tahun ke atas di Indonesia pada tahun 2015 selama 12.55 tahun, berarti harapan lama sekolah di Kalimantan Tengah lebih rendah 0.33 tahun. Harapan lama sekolah nasional selalu mengalami kenaikan dari tahun 2010 sebesar 11.29 tahun. Rata-rata pertumbuhan harapan lama sekolah Nasional 2.23 persen. Berarti secara nilai, rata-rata pertumbuhan lama sekolah di Indonesia lebih tinggi dari pada di Kalimantan Tengah. Hal ini harus menjadi perhatian serius Pemerintah Daerah di Provinsi Kalimantan Tengah baik provinsi maupun kabupaten/kota karena harapan lama sekolah merupakan salah satu indikator proses pembangunan program pendidikan jangka pendek.

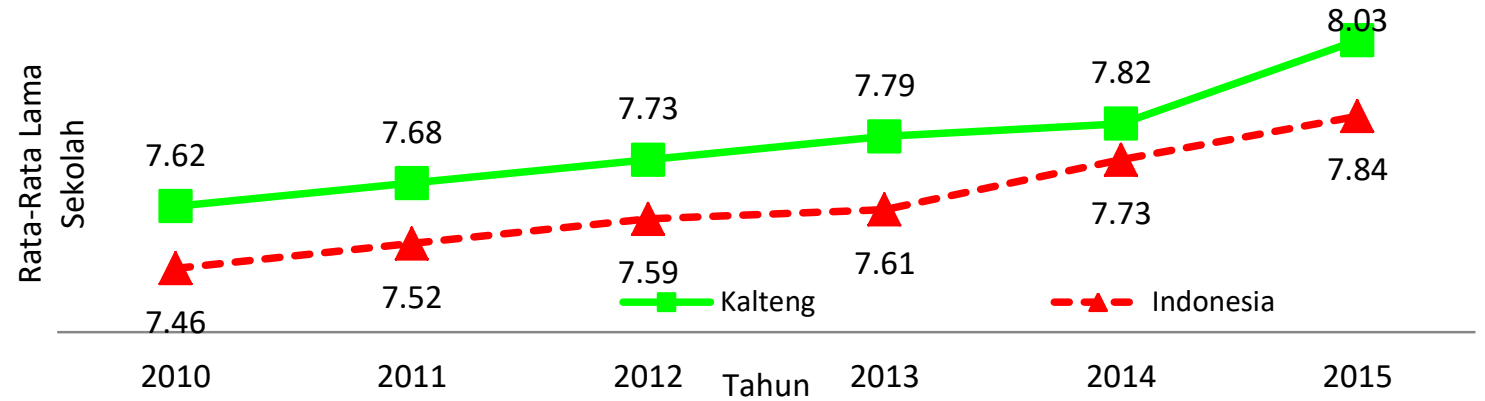

Sumber: Badan Pusat Statistik (diolah)

Gambar 4. Pengeluaran Per Kapita Kalimantan Tengah dan Indonesia (Rupiah), 2010-2015

Rata-rata lama sekolah penduduk usia 25 tahun keatas di Kalimantan Tengah pada tahun 2015 adalah selama 8.3 tahun. Berarti rata-rata lama sekolah penduduk usia 25 tahun keatas belum menamatkan SLTP. Pencapaian Kalimantan Tengah pada tahun 2015 lebih tinggi karena telah sampai di kelas 8, sedangkan Nasional masih di kelas 7.

Selama 5 tahun rata-rata lama sekolah di Kalimantan Tengah telah meningkat 0.41 tahun atau 5.38 persen. Rata-rata pertumbuhan lama sekolah setiap tahun 1.08 persen. Rata-rata lama

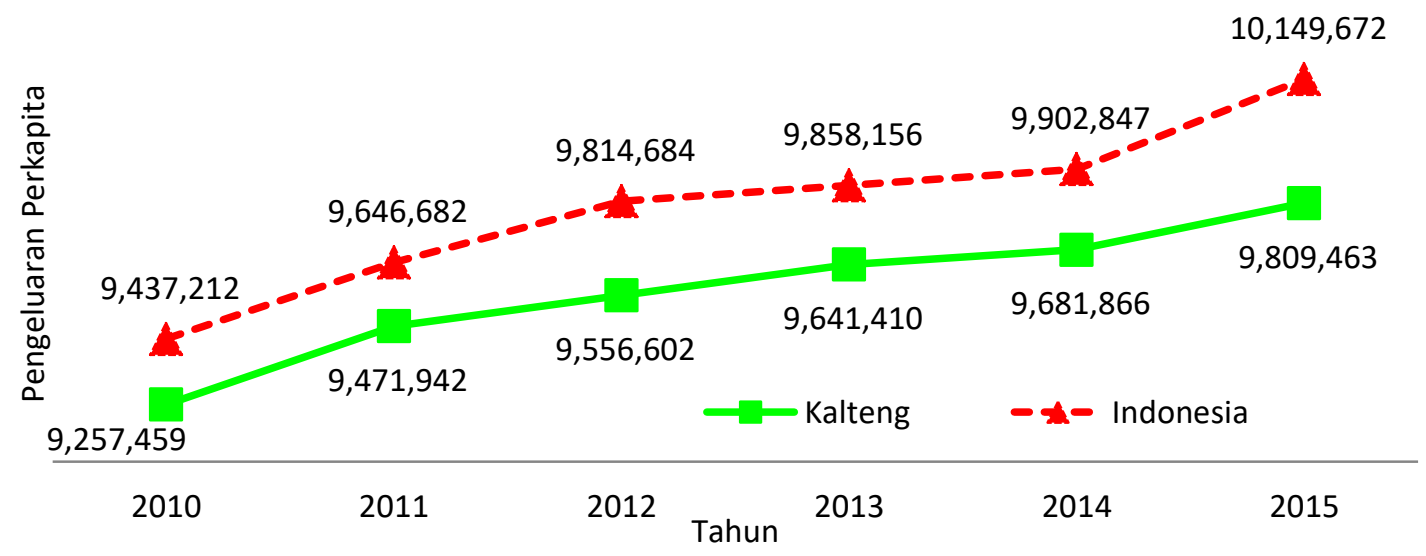

Sumber: Badan Pusat Statistik (diolah)

Gambar 5. Rata-Rata Lama Sekolah Kalimantan Tengah dan Indonesia (Tahun), 2010-201 sekolah penduduk usia 25 tahun keatas Nasional pada tahun 2015 adalah 7.84 tahun. Dalam jangka waktu 5 tahun telah naik sebesar 0.38 tahun atau 5.09 persen. Rata-rata pertumbuhan lama sekolah naik 1.02 persen setiap tahun. Pertumbuhan ratarata lama sekolah di Kalimantan Tengah lebih tinggi dari pertumbuhan Nasional. Dari tren data 2010-2015, di Kalimantan Tengah terjadi pelambatan pertumbuhan di tahun 2014, sementara tingkat Nasional terjadi pelambatan pada tahun 2014. 
Dari empat indikator penyusun IPM, hanya indikator rata-rata lama sekolah yang nilai Kalimantan Tengah lebih tinggi dari angka Nasional. Indeks rata-rata lama sekolah merupakan indeks penyusun IPM yang nilainya paling kecil, baik untuk provinsi maupun kabupaten/kota di Kalimantan Tengah. Dengan lebih tinggi nilai indeks rata-rata lama sekolah di Kalimantan Tengah, diharapkan nilai IPM Kalimantan Tengah dapat meningkat lebih cepat.

\section{Dimensi Standar Hidup Layak}

Standar hidup layak merupakan dimensi terakhir dalam membentuk angka indeks pembangunan manusia. Dimensi ini diwakili oleh indikator pengeluaran per kapita yang disesuaikan. Pengeluaran per kapita yang digunakan adalah dengan tahun dasar 2012 yang sudah disesuaikan antar daerah di Indonesia.

Pada tahun 2015, pengeluaran per kapita masyarakat Kalimantan Tengah mencapai Rp 9 809463 per tahun. Selama lima tahun terakhir, pengeluaran perkapita selalu mengalami kenaikan seperti terlihat pada gambar di atas. Selama 5 tahun pengeluaran perkapita telah naik sebesar Rp 552004 atau Rp 110400 per tahun. Pengeluaran per kapita Nasional pada tahun 2015 Rp 10149 672. Pengeluaran perkapita yang disesuikan di Indonesia mengalami kenaikan dari tahun ke tahun. Selama lima tahun terakhir pengeluaran per kapita meningkat 1.51 persen.

\section{Indeks Pembangunan Manusia Kabupaten/Kota di Kalimantan Tengah}

Hubungan antara nilai IPM dan laju IPM di tingkat kabupaten/kota di Kalimantan Tengah terlihat pada gambar 6. Analisis yang digunakan adalah analisis Kuadran. Analis Garis vertikal pada nilai IPM adalah rata-rata nilai IPM kabupaten/ kota di Provinsi Kalimantan Tengah sedangkan garis horizontal adalah rata-rata laju IPM.

Kuadran I menggambarkan wilayah dengan nilai IPM di atas rata-rata dengan laju IPM juga diatas rata-rata. Kabupaten/kota yang masuk kuadran I pada tahun 2011 hanya Kabupaten Lamandau. Meskipun nilai IPM Kabupaten Lamandau hanya sedikit diatas rata-rata, tetapi dapat menunjukkan bahwa Kabupaten Lamandau memiliki nilai IPM yang tinggi dan cenderung semakin meningkat nilai IPM tersebut. Pada tahun 2015 berganti Kabupaten Gunung Mas yang berada di kuadran I. Berarti pada tahun 2015 Kabupaten Gunung Mas memiliki nilai IPM yang tinggi dan cenderung semakin meningkat nilai IPM tersebut.

Kabupaten/kota yang berada pada kuadran II memiliki nilai IPM yang tinggi tetapi memiliki laju IPM yang lambat. Kabupaten/kota pada kuadran II masih mungkin meningkatkan laju IPM apabila peningkatan nilai IPM dapat lebih tinggi. Pada tahun 2011 yang masuk ke kuadran II yaitu Kota Palangka Raya, Kabupaten Kotawaringin Barat, Kabupaten Gunung Mas dan Kabupaten Barito Timur. Pada tahun 2015 yang masuk di kuadran II yaitu Kota Palangka Raya, Kabupaten Kotawaringin Barat, Kabupaten Kotawaringin Timur, dan Kabupaten Barito Timur. Kabupaten Kotawaringin Timur telah naik dari kuadran III ke kuadran II, begitu juga Kabupaten Gunung Mas meningkat dari Kuadran II ke kuadran I pada tahun 2015.

Kuadran III merupakan wilayah dengan nilai IPM yang rendah dengan laju IPM yang rendah pula. Perlu usaha yang keras untuk meningkatkan nilai IPM pada kuadran ini. Tahun 2011 kabupaten/kota yang berada pada kuadran III yaitu Kabupaten Kotawaringin Timur, Kabupaten Barito Utara, Kabupaten Sukamara dan Kabupaten Pulang Pisau. Untuk Kabupaten Barito Utara dan Kabupaten Seruyan antara kuadran III dan IV karena laju IPM berada pada rata-rata kabupaten/kota se Kalimantan Tengah. Pada tahun 2015 yang masuk kuadran III adalah Kabupaten Lamandau, Kabupaten Kapuas, Kabupaten Pulang Pisau dan Kabupaten Murung Raya. 

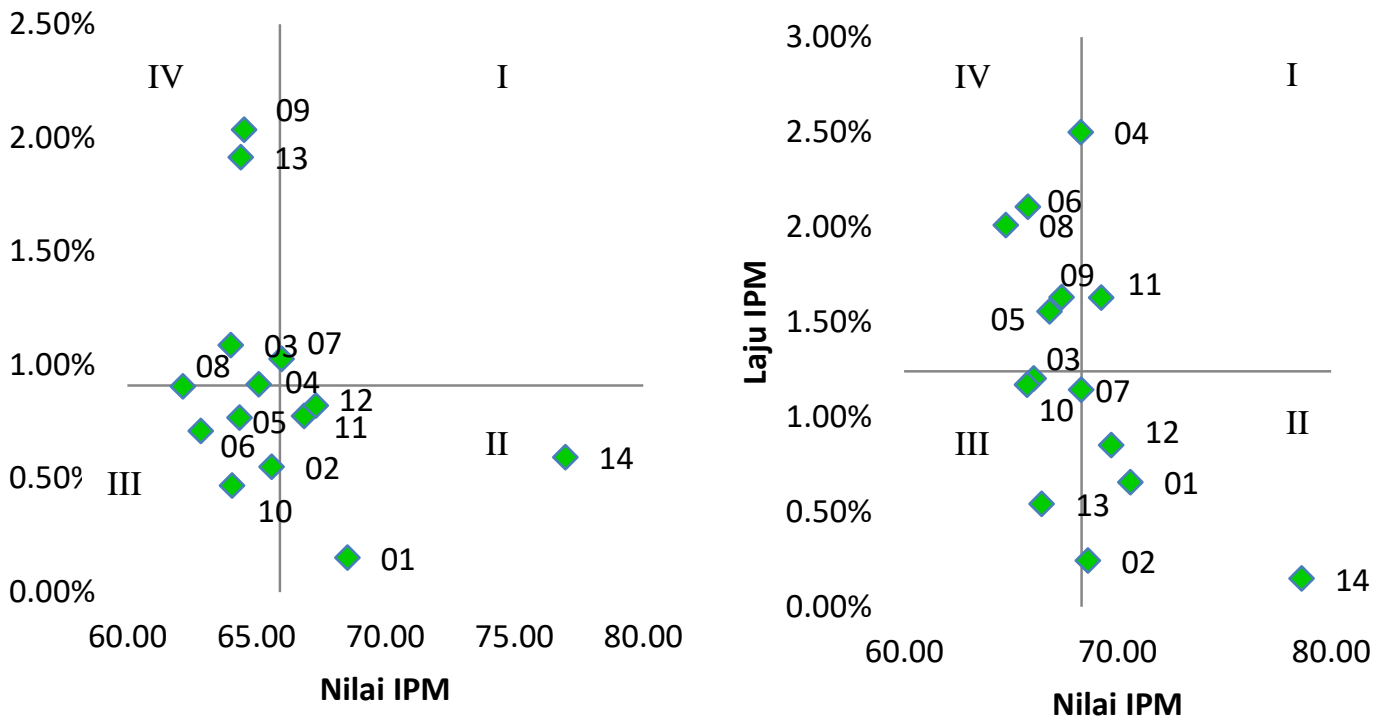

Sumber: Badan Pusat Statistik (diolah)

Ket:

$\begin{array}{ll}\text { 01. Kab. Kotawaringin Barat } & \text { 06. Kab. Sukamara } \\ \text { 02. Kab. Kotawaringin Timur } & \text { 07. Kab. Lamandau } \\ \text { 03. Kab. Kapuas } & \text { 08. Kab. Seruyan } \\ \text { 04. Kab. Barito Selatan } & \text { 09. Kab. Katingan } \\ \text { 05. Kab. Barito Utara } & \text { 10. Kab. Pulang Pisau }\end{array}$

11. Kab. Gunung Mas

12. Kab. Barito Timur

13. Kab. Murung Raya

14. Kota Palangka Raya

Gambar 6. Nilai dan Laju IPM kabupaten/kota di Provinsi Kalimantan Tengah, 2011 dan 2015

Kabupaten/Kota yang berada pada kuadran IV memiliki laju IPM yang tinggi, tetapi nilai IPM yang lebih rendah dari rata-rata. Dengan laju pertumbuhan yang tinggi memungkinkan kabupaten/ kota tersebut untuk terus meningkatkan nilai IPM dengan memanfaatkan segala sumber daya yang ada untuk mengejar ketertinggalan dari kabupaten/kota yang lebih tinggi nilai IPM-nya. Tahun 2011 kabupaten/kota yang masuk di kuadran IV yaitu Kabupaten Kapuas, Kabupaten Katingan dan Kabupaten Murung Raya. Pada tahun 2015 yang masuk kuadran IV yaitu Kabupaten Barito Selatan, Kabupaten Barito Utara, Kabupaten Sukamara dan Kabupaten Seruyan.

IPM tahun 2011 terlihat lebih mengelompok mendekati dan kuadran II dibanding tahun 2015. Kabupaten yang masuk kuadran III memang hanya ada empat kabupaten, tetapi ada enam kabupaten yang berada mendekati kuadran III. Nilai IPM tahun 2015 terlihat lebih menyebar dan tidak lagi mengelompok mendekati kuadran III. Ada perbaikan dari penyebaran nilai IPM.

Kota Palangka Raya terlihat memiliki nilai IPM yang jauh lebih tinggi dibanding dengan kabupaten lain di Kalimantan Tengah, terlihat pada gambar 9 dan gambar 10. Walaupun memiliki laju IPM yang lambat, tetapi nilai IPM Kota Palangka Raya belum dapat dikejar oleh kabupaten lain. Peringkat dua sampai dengan peringkat empat nilai IPM tidak mengalami perubahan dari tahun 2011 sampai dengan tahun 2015 yaitu berturut-turut Kabupaten Kotawaringin Barat, Kabupaten Barito Timur dan Kabupaten Gunung Mas.

Kabupaten Seruyan dan Kabupaten Pulang Pisau adalah kabupaten yang perlu perhatian karena memiliki nilai dan laju IPM yang rendah. Kabupaten Seruyan pada tahun 2011 sampai dengan tahun 2015 selalu memiliki nilai IPM yang paling rendah jika dibandingkan dengan nilai IPM kabupaten/ kota di Kalimantan Tengah. Meski laju IPM Kabupaten Seruyan telah baik pada tahun 2015, hal ini tetap harus menjadi perhatian serius bagi pemerintah daerah, baik provinsi Kalimantan Tengah maupun Kabupaten Seruyan. Diperlukan kerja yang lebih keras lagi agar nilai IPM Kabupaten Seruyan dapat meningkat lebih cepat.

Kabupaten/kota yang masih tetap di kuadran 3 pada tahun 2011 dan 2015 hanyalah Kabupaten 
Pulang Pisau. Nilai IPM yang rendah dengan laju yang rendah pula membuat peringkat IPM Kabupaten Pulang Pisau menurun. Pada tahun 2011 peringkat IPM Kabupaten Pulang Pisau berada pada urutan 11 sedangkan pada tahun 2015 sudah ada di peringkat 13. Perlu ada evaluasi pembangunan di Kabupaten Pulang Pisau yang menyebabkan nilai IPM menurun.

\section{Pemilihan Model Terbaik}

Data yang digunakan pada penelitian ini adalah data panel yang diambil dai penggabungan cross section antar kabupaten/kota di Provinsi Kalimantan Tengah dan data deret waktu antara tahun 2010-2015. Terdapat 3 pendekatan dalam perhitungan model regresi data panel yaitu Pooled Least Square (PLS), model efek tetap (fixed effect model/FEM) dan model efek acak (random effect model/REM). Untuk memilih salah satu dari ketiga model diatas digunakan beberapa uji yaitu uji chow, uji lagrange multiplier (LM) dan uji Hausman. Uji Chow untuk menentukan penggunaan FEM atau PLS, uji LM untuk menentukan penggunaan PLS atau REM dan uji hausman untuk menentukan penggunaan REM atau FEM.

Tabel 2. Hasil Pemilihan Uji terbaik

\begin{tabular}{rc}
\hline Uji Model Terbaik & Probabilitas Chi-Sq \\
\hline Uji Breusch-Pagan I & 0.0000
\end{tabular}

Uji Hausman

0.4019

Sumber: Hasil olahan E-views 9

Pada metode ini dapat dilihat bahwa hasil probabilitas uji Hausman menunjukan nilai probabilitas sebesar 0.4019 yang menunjukan model REM lebih baik dari pada model FEM. Hasil Uji LM menunjukan tolak $\mathrm{H}_{0}$ karena nilai probability sebesar 0.000 berarti intersep merupakan peubah random. Jadi model estimasi yang tepat untuk regresi data panel adalah metode efek acak (REM).

Tabel 3. Hasil Estimasi Model Penelitian

\begin{tabular}{ccc}
\hline Variabel & Koefisien & Probabilitas \\
\hline Tingkat Kemiskinan & -0.1926 & $0.0294^{* *}$ \\
PDRB perKapita & 3.3920 & $0.0078 * * *$ \\
APBD Kesehatan & 0.7686 & $0.0007 * * *$ \\
APBD Pendidikan & -0.0486 & 0.3527 \\
Rasio Ketergantungan & -0.2878 & $0.0000^{* * *}$ \\
Tk Pengangguran & 0.0929 & $0.0007 * * *$ \\
Variabel Dummy & 8.9183 & $0.0003 * * *$ \\
C & 5.1088 & 0.8225 \\
\hline
\end{tabular}

Ket: Tanda $* * *$ dan $* *$ menandakan signifikan pada 1 persen dan 5 persen

Sumber: Hasil olahan E-views 9

\section{Hasil Uji Statistik}

Terdapat beberapa pengujian secara statistik diantaranya koefisien determinasi $\left(\mathrm{R}^{2}\right)$ dan Uji $\mathrm{F}$ Statistik. Koefisien determinasi $\left(\mathrm{R}^{2}\right)$ model sebesar 0.9076. Berarti 90 persen variabel dependen mampu dijelaskan oleh keragaman variabel independen. Nilai $\mathrm{R}^{2}$ model mendekati 1 pada model tersebut berarti keragaman variabel independen mampu menjelaskan keragaman variabel dependen.

Nilai probabilitas F-statistik model menunjukan nilai $\alpha$ kurang dari 5 persen. Nilai tersebut menunjukan variabel independen yang digunakan pada secara bersama-sama mampu menjelaskan variabel dependen. 


\section{Interpretasi Model}

Hasil pengolahan data menggunakan software E-views 9 dengan menggunakan model random effects seperti pada Tabel 3. Variabel independen yang secara signifikan berpengaruh terhadap nilai indeks pembangunan manusia di Provinsi Kalimantan Tengah pada taraf nyata 5 persen adalah persentase kemiskinan, PDRB perkapita, alokasi APBD untuk kesehatan, rasio ketergantungan dan tingkat pengangguran terbuka. Variabel alokasi APBD untuk pendidikan tidak signifikan memengaruhi IPM Kalimantan Tengah

Kemiskinan berpengaruh secara signifikan terhadap indeks pembangunan manusia karena memilki probabilitas 0.0294. Nilai koefisien regresi presentase kemiskinan sebesar -0.192. Dari hasil koefisien menyatakan bahwa pada kondisi cateris paribus, bila presentase kemiskinan menurun sebanyak 1 persen, maka secara rata-rata indeks pembangunan manusia akan naik sebesar 0.192 poin. Hasil ini sesuai dengan peneliti terdahulu oleh Sofihilda et al (2013) bahwa kemiskinan dan indeks pembangunan manusia memiliki hubungan simultan yang berlainan arah. Kemiskinan memiliki pengaruh terhadap indeks pembangunan manusia di semua dimensi.

PDRB perkapita menjadi variabel independen yang secara parsial memiliki pengaruh yang signifikan teradap indeks pembangunan manusia. Signifikansi dapat dilihat dari nilai probabilitasnya nilai t-statistik sebesar 0.0078. Nilai koefisen pengaruh PDRB per kapita terhadap IPM sebesar 3.392, berarti apabila PDRB per kapita naik sebesar 1 persen, maka IPM akan meningkat sebesar 3 392 poin. Hasil penelitian ini sesuai dengan penelitian Sa'diyah (2014) yang menunjukan PDRB perkapita me-miliki hubungan yang positif dan signifikan terhadap indeks pembangun-an manusia di Nusa Tenggara Barat. Nilai signifikansi tersebut merupakan nilai yang tertinggi untuk memengaruhi indeks pembangunan manusia dalam penelitian ini. Hal ini mungkin karena pertambahan output perkapita suatu wilayah tidak hanya berpengaruh terhadap pendapatan seseorang, tetapi ada efek multiplier dimana kesehatan dan pendidikan juga meningkat sehingga meningkatkan pembangunan manusia.

Tabel 4. Share dan Pertumbuhan PDRB Provinsi Kalimantan Tengah, 2015

\begin{tabular}{lcc}
\hline \multicolumn{1}{c}{ LAPANGAN USAHA } & SHARE & PERTUMBUHAN \\
\hline Pertanian, Kehutanan, dan Perikanan & 22.84 & 5.32 \\
Pertambangan dan Penggalian & 10.77 & 2.04 \\
Industri Pengolahan & 16.15 & 6.41 \\
Pengadaan Listrik dan Gas & 0.07 & 25.54 \\
Pengadaan Air, Sampah, dan Daur Ulang & 0.10 & 3.32 \\
Konstruksi & 9.15 & 9.62 \\
Perdagangan dan Reparasi & 11.64 & 8.29 \\
Transportasi dan Pergudangan & 6.73 & 13.57 \\
Penyediaan Akomodasi dan Makan Minum & 1.87 & 8.28 \\
Informasi dan Komunikasi & 1.01 & 5.23 \\
Jasa Keuangan dan Asuransi & 3.25 & 2.16 \\
Real Estat & 2.17 & 8.56 \\
Jasa Perusahaan & 0.04 & 7.84 \\
Administrasi Pemerintahan, dan Jamsos & 6.48 & 15.34 \\
Jasa Pendidikan & 4.81 & 10.47 \\
Jasa Kesehatan dan Kegiatan Sosial & 1.89 & 9.73 \\
Jasa lainnya & 1.03 & 7.56 \\
\hline PDRB Kalimantan Tengah & $\mathbf{1 0 0 . 0 0}$ & $\mathbf{7 . 0 1}$ \\
\hline Sunber: BPS Provins Kaliman Tengah & & \\
\hline
\end{tabular}

Sumber: BPS Provinsi Kalimantan Tengah, 2016 
Sektor pertanian masih dominan di Kalimantan Tengah. Tahun 2015 share sektor pertanian sebesar 22.84 persen dengan pertumbuhan sebesar 5.32 persen. Share terbesar berikutnya adalah sektor industri pengolahan sebesar 16.15 persen. Kedua sektor tertinggi tersebut bersumber dari hulu yang sama yaitu perkebunan kelapa sawit (BPS Prov. Kalteng, 2016). Subsektor perkebunan tahunan mendominasi share di sektor pertanian dan komoditi kepala sawit mendomisasi subsektor perkebunan tahunan. Sektor industri pengolahan didominasi oleh industri Crude Palm Oil (CPO) dan turunannya. CPO adalah industri turunan dari produk kelapa sawit.

Komoditas kelapa sawit telah mendominasi perekonomian di Kalimantan Tengah. Aktivitas perkebunan menghasilkan tandan buah segar (TBS) yang meningkatkan nilai tambah sektor pertanian, kehutanan dan perikanan. TBS sawit diolah melalui proses industri untuk menghasilkan CPO sebelum dapat diperdagangkan. Tahapan pembuatan CPO menghasilkan nilai tambah pada sektor industri pengolahan subsektor industri makanan dan minuman. Meskipun CPO masih produk mentah namun sudah menghasilkan dua output yang menggerakkan perekonomian. Untuk menghasilkan produk akhir seperti minyak goreng, bahan bakar dan kosmetik CPO masih perlu pengolahan lebih lanjut. Industri minyak goreng hanya ada satu di wilayah Kalimantan Tengah (BPS Prov. Kalteng, 2016), sehingga CPO masih banyak yang dibawa ke luar Kalimantan Tengah.

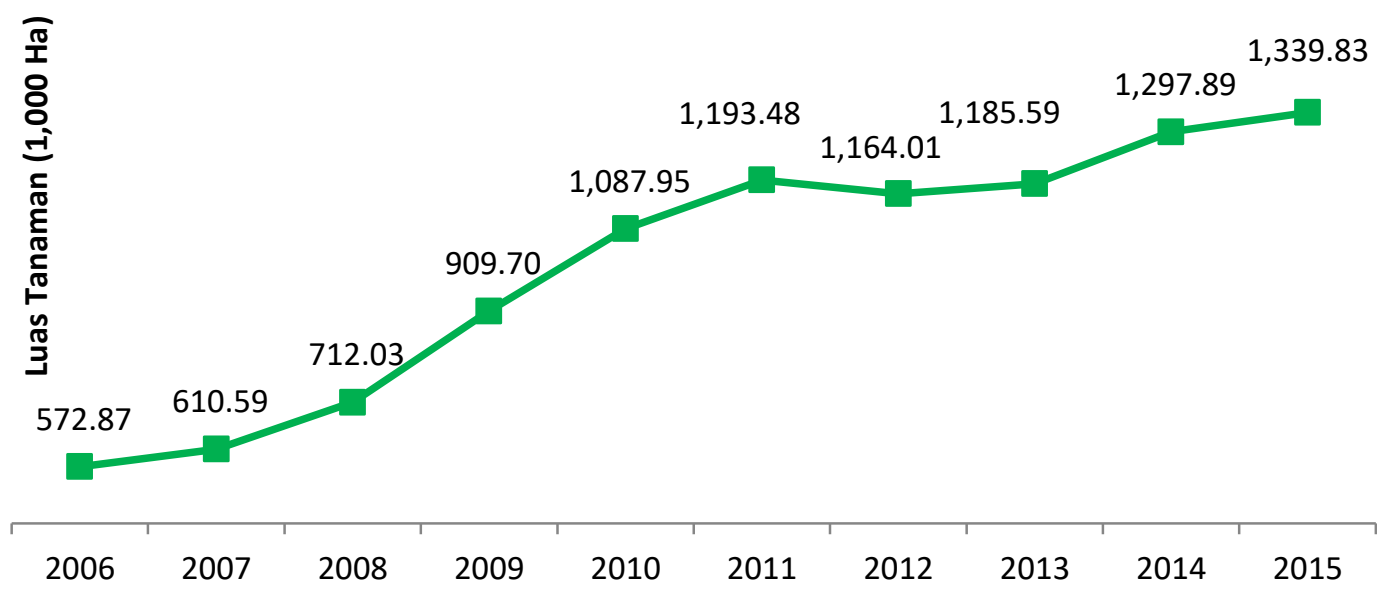

Sumber : BPS Provinsi Kalimantan Tengah (diolah)

Gambar 7. Luas Areal Tanaman Kelapa Sawit di Provinsi Kalimantan Tengah, Tahun 2006-2015

Luas areal tanaman sawit tahun 2015 telah meningkat sebesar 133.88 persen dibandingkan tahun 2006 (Gambar 7). Apabila CPO yang dihasilkan dari perkebunan di Kalimantan Tengah dapat diolah menjadi produk akhir sebelum dibawa keluar Kalimantan Tengah, maka akan meningkatkan PDRB Kalimantan Tengah. Nilai tambah yang dihasilkan oleh sektor industri lebih tinggi dari sektor pertanian, oleh karena itu perlu penambahan industri akhir dari turunan kelapa sawit seperti minyak goreng, bahan bakar atau kosmetik di Kalimantan Tengah. Harga CPO di pasar sering mengalami naik turun, dengan adanya industri akhir di Kalimantan Tengah akan menstabilkan harga ditingkat petani kecil karena hasil mereka akan tetap diserap oleh industri lokal.

Untuk meningkatkan PDRB dari komoditas kelapa sawit dapat dengan menggunakan kluster industri kelapa sawit. Dengan adanya kluster industri akan meningkatkan komoditas kelapa sawit dari hulu ke hilir. Industri hulu seperti industri pupuk dan benih yang akan digunakan oleh perkebunan kelapa sawit. Industri hilir seperti pengolahan industri akhir yang tidak hanya sampai CPO. Sektor lain yang dapat dikembangkan dari kelapa sawit adalah perdagangan, peternakan sapi potong, pendidikan dan pariwisata. 
Sektor perdagangan dapat meningkat saat nilai ekspor hasil akhir yang memiliki lebih tinggi diperdagangkan ke luar wilayah. PDRB sektor peternakan naik saat pola integrasi sapi sawit lebih digalakkan. Sapi akan memakan sisa TBS hasil industri CPO dan perkebunan mendapat tambahan pupuk kandang. Selain itu dengan integrasi sapi sawit dapat meningkatkan jumlah sapi yang ada di Indonesia sehingga dapat membantu program pemerintah dalam swasembada daging. Dari sektor pendidikan dapat didirikan pusat penelitian kelapa sawit dari hulu sampai ke hilir. Selain itu dapat pula didirikan perguruan tinggi yang fokus pada komoditas kelapa sawit. Sektor pariwisata dapat maju karena jika dikelola dengan baik perkebunan kelapa sawit bisa menjadi objek wisata yang menarik. Hasil akhir dari peningkatan PDRB adalah meningkatkan Indeks Pembangunan Manusia di Provinsi Kalimantan Tengah, karena sesungguhnya IPM juga merupakan indikator pembangunan.

Belanja pemerintah daerah pada dasarnya adalah kebijakan fiskal yang dilakukan oleh pemerintah provinsi maupun kabupaten/kota. Dalam penelitian ini terdapat dua jenis kebijakan fiskal yang diperoleh dari pengeluaran menurut fungsi, yaitu fungsi kesehatan dan pendidikan. Koefisien regresi APBD untuk alokasi kesehatan sebesar 0.768 dengan nilai probabilitas t-statistik sebesar 0.0007. Secara statistik alokasi APBD untuk kesehatan berpengaruh signifikan terhadap indeks pembangunan manusia di Kalimantan
Tengah. Pada kondisi cateris paribus, apabila alokasi APBD untuk sektor kesehatan meningkat 1 pesen, maka indeks pembangunan manusia di Kalimantan Tengah akan meningkat sebesar 0.768. Alokasi APBD untuk sektor pendidikan tidak signifikan memengaruhi IPM di Kalimantan Tengah karena memiliki nilai probabilitas tstatistik sebesar 0.3257. Hal ini mungkin karena kebijakan pendidikan merupakan kebijakan jangka panjang. Sehingga peningkatan alokasi anggaran pada sektor pendidikan tidak dapat langsung dinikmati dengan peningkatan pendidikan. Misalnya ada pembangunan sekolah, tidak dapat langsung meluluskan siswa pada tahun yang bersangkutan. Ada kelambatan (lag) waktu antara peningkatan alokasi APBD sektor pendidikan dengan pencapaian pembangunan manusia. Hal ini tentu berbeda dengan alokasi APBD untuk sektor kesehatan yang dapat langsung dilihat hasilnya pada pembangunan manusia.

Variabel rasio ketergantungan (dependency ratio) berpengaruh signifikan negatif terhadap indeks pembangunan manusia di Kalimantan Tengah. Hasil ini dapat dilihat dari nilai koefisien regresi sebesar -0.287 dengan nilai probabilitas tstatistik 0.0000. Artinya penurunan rasio ketergantungan sebesar 1 poin akan meningkat nilai pembangunan manusia sebesar 0.287 poin. Hal ini sesuai dengan penelitian oleh Pratowo (2012) yang menyatakan rasio ketergantungan memiliki pengaruh negatif terhadap indeks pembangunan manusia di Provinsi Jawa Tengah.

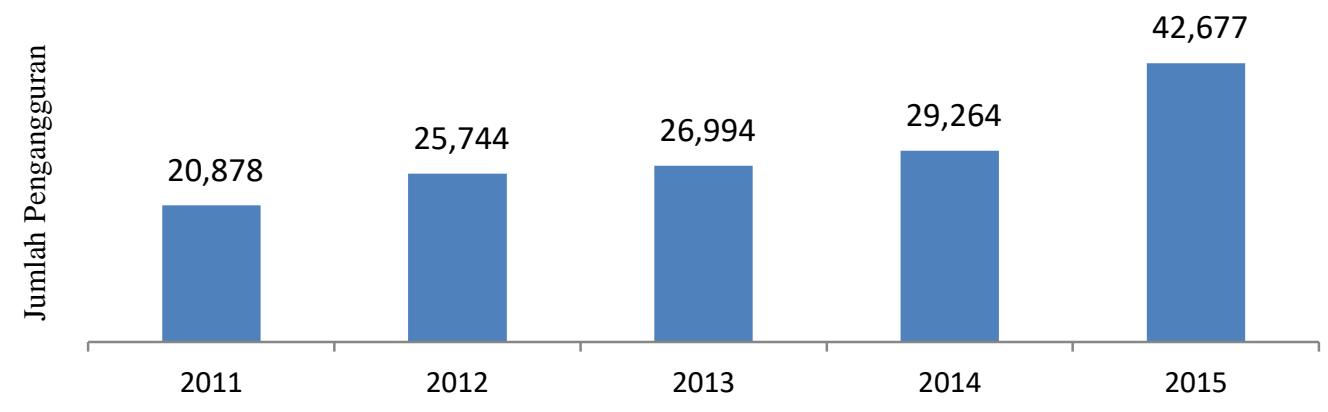

Sumber: BPS Prov. Kalteng (diolah

Gambar 8. Jumlah Pengangguran yang Telah Menamatkan Pendidikan SLTP Sederajat Keatas Kalimantan Tengah (jiwa), 2011-2015

Tingkat pengangguran terbuka padahasil estimasi yang dilakukan, memiliki koefisien yang positif dan signifikan karena memiliki probabilitas t-statistik sebesar 0.0007. Hasil ini berbeda dengan 
hipotesis awal dan penelitian sebelumnya yang dilakukan oleh Hamzah et al (2012) yang menyatakan hubungan antara tingkat pengangguran dan indeks pembangunan manusia adalah negatif. Hal ini mungkin karena adanya peningkatan pengangguran terdidik di Kalimantan Tengah

Dengan semakin meningkatnya rata-rata lama sekolah, akan meningkatkan nilai IPM. Tetapi hal ini tidak diikuti dengan penyerapan tenaga kerja, sehingga pengangguran berpendidikan SLTP keatas justru semakin meningkat. Permasalahan kondisi keadaan tenaga kerja di Indonesia termasuk di Kalimantan Tengah adalah rendahnya mutu keterampilan kerja dalam memahami deskripsi tugas kerja yang diinginkan pengguna tenaga kerja (Damanhuri et al, 2014). Rendahnya keterampilan mengindikasikan adanya celah yang harus disesuaikan antara kurikulum pendidikan dan kebutuhan lembaga penyerap tenaga kerja. Hal ini menjadi permasalahan serius dari ke tenagakerjaan di Kalimantan Tengah dimana harapannya ketika

semakin tinggi tingkat pendidikan seharusnya semakin mudah pula mendapatkan pekerjaan. Solusi jangka pendek adalah mengadakan pelatihan agar keterampilan masyarakat meningkat melalui BLK (Balai Latihan Kerja). Solusi jangka panjang dengan memperbaiki kurikulum pendidikan secara konsisten dan berkelanjutan.

Wilayah kota terbukti memiliki nilai pembangunan manusai yang lebih tinggi dari wilayah kabupaten di Provinsi Kalimantan Tengah. Hal ini terlihat dari variabel dummy yang bernilai positif dan signifikan. Terjadi kesenjangan nilai IPM antara wilayah kota dan kabupaten. Wilayah kota yang ada di Provinsi Kalimantan Tengah hanya Kota Palangka Raya. Selama tahun 20102015 Kota Palangka Raya secara statistik memiliki nilai IPM yang berbeda dengan nilai IPM kabupaten di Provinsi Kalimantan Tengah. Dengan koefisien sebesar 8.918 berarti nilai IPM Kota Palangka Raya lebih tinggi sebesar 8.918 dibanding IPM kabupaten di Provinsi Kalimantan Tengah

Tabel 5. Jumlah Perguruan Tinggi (PT) Berstatus Aktif Beserta Jumlah Mahasiswa menurut Kabupaten/Kota, 2016

\begin{tabular}{lcc}
\hline \multicolumn{1}{c}{ Kabupaten/kota } & Jumlah PT Aktif & Jumlah Mahasiswa \\
\hline Kotawaringin Barat & 2 & 1674 \\
Kotawaringin Timur & 6 & 2918 \\
Kapuas & 4 & 507 \\
Barito Selatan & 2 & 291 \\
Barito Utara & 3 & 634 \\
Katingan & 1 & 0 \\
Barito Timur & 1 & 0 \\
Palangka Raya & 16 & 22257 \\
Jumlah & 35 & 28281 \\
\hline
\end{tabular}

Sumber : Dikti, 2016

Pada Gambar 9 terlihat jumlah dokter baik dokter umum, dokter gigi maupun dokter spesialis di Kota Palangka Raya memiliki jumlah sangat besar jika dibandingkan dengan wilayah lain di Kalimantan Tengah dengan jumlah sebesar 204 dokter. Jumlah dokter terbanyak selanjutnya adalah Kabupaten Kowaringin Timur dan Kabupaten Kotawaringin Timur dengan jumlah masingmasing 81 dan 80 dokter. Terlihat sekali ada ketimpangan penempatan dokter di Kalimantan Tengah. Tentu hal ini dapat membuat derajat kesehatan masyarakat di wilayah kota dan kabupaten dapat berbeda. Apalagi bahwa jarak antar kabupaten di Kalimantan Tengah berjauhan, membuat akses terhadap dokter menjadi lebih sulit. Perlu terobosan dari pengambil kebijakan untuk mengatasi hal ini. 


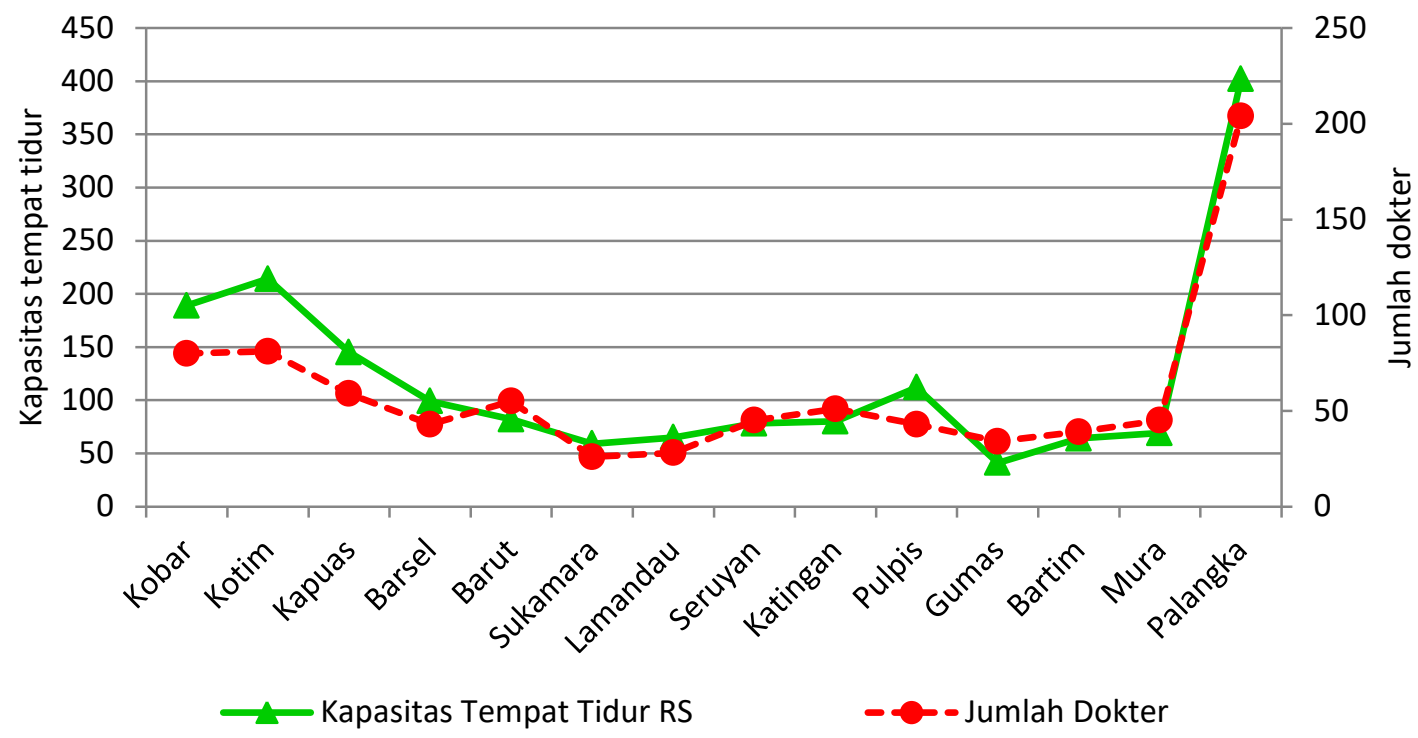

Sumber : BPS Prov. Kalteng (diolah)

Gambar 9. Jumlah Dokter dan Jumlah Tempat Tidur Rumah Sakit Menurut Kabupaten/Kota di Kalimantan Tengah, 2014

Dilihat dari sisi pendidikan, terjadi ketimpangan jumlah perguruan tinggi yang berada di Kota Palangka Raya seperti terlihat pada Tabel 3. Dari 35 perguruan tinggi (PT) yang aktif di Kalimantan Tengah, hampir setengah atau 45 persen berada di Kota Palangka Raya. Dari jumlah mahasiswa, 78.70 persen jumlah mahasiswa ada di Kota Palangka Raya. Hal ini dapat menyebabkan nilai IPM Kota Palangka Raya menjadi lebih tinggi dibanding kabupaten di Provinsi Kalimantan Tengah.

\section{SIMPULAN DAN SARAN Simpulan}

Berdasarkan hasil penelitian yang sudah dilakukan maka diperoleh kesimpulan sebagai berikut:

1. Dari empat indikator penyusun IPM, tiga indikator Kalimantan Tengah nilainya lebih kecil dari indikator Nasional yaitu angka harapan hidup, harapan lama sekolah dan pengeluaran perkapita yang disesuaikan. Hanya ada satu indikator penyusun IPM Kalimantan Tengah yang lebih tinggi dari angka Nasional yaitu rata-rata lama sekolah.

2. Hasil estimasi menggunaan data panel model efek acak (REM) menunjukan bahwa PDRB perkapita, alokasi APBD untuk kesehatan, tingkat pengangguran terbuka dan dummy kota kabupaten memiliki pengaruh yang signifikan dan positif. Kemiskinan dan rasio ketergantungan memiliki pengaruh signifikan dan negatif. Variabel yang tidak berpegaruh signifikan pada IPM di Kalimantan Tengah adalah alokasi APBD untuk sektor pendidikan.

\section{Saran}

1. PDRB perkapita memiliki pengaruh yang paling tinggi terhadap IPM di Provinsi Kalimantan Tengah. Sektor pertanian dan sektor industri memiliki share paling tinggi pada PDRB dengan komoditas utama pada kedua sektor tersebut adalah kelapa sawit. Pengembangan kelapa sawit perlu diarahkan menuju kluster industri dari hulu ke hilir. Dalam klaster tersebut terdapat peningkatan PDRB dari industri pupuk, industri akhir kelapa sawit, perdagangan, peternakan sapi potong, pusat penelitian dan pariwisata.

2. Pemerintah daerah perlu meningkatkan APBD pada sektor kesehatan secara berkelanjutan. Pengeluaran sektor kesehatan dapat diarahkan untuk memperkuat layanan dasar kesehatan 
pada puskesmas dan pusat serta pelayanan rumah sakit daerah sebagai rujukan. Perluasan jaminan kesehatan melalui BPJS kepada masyarakat hampir miskin dan pekerja informal bagi yang tidak tercakup pada data nasional agar masyarakat tidak terbebani dengan iuran BPJS mandiri.

3. Semakin tingginya pengangguran terbuka untuk pendidikan SLTP ke atas mengindikasikan rendahnya keterampilan dan adanya celah antara kurikulum pendidikan dan lembaga penyerap tenaga kerja. Solusi jangka pendek adalah dengan mengadakan pelatihan agar keterampilan masyarakat meningkat. Solusi jangka panjang dengan memperbaiki kurikulum pendidikan di Indonesia terutama dari pendidikan vokasi dari tingkat sekolah menengah kejuruan (SMK), hingga pendidikan vokasi di perguruan tinggi.

4. Diperlukan pemerataan pengadaan tenaga dokter dan perguruan tinggi agar pembangunan manusia tidak hanya pada ibu kota provinsi. Selain itu, alokasi APBD untuk pendidikan perlu dikaji lagi efektifitasnya agar lebih tepat sasaran.

5. Rata-rata lama sekolah harus lebih ditingkatkan karena dalam penghitungan ratarata geometrik menjadi beban penghitungan IPM. Terutama bagi Kabupaten Seruyan dan Kabupaten Pulang Pisau untuk dapat mengejar nilai IPM dengan wilayah lain di Kalimantan Tengah. Strategi yang digunakan yaitu meningkatkan pendidikan bagi penduduk berusia 25 tahun keatas yang belum mencapai pendidikan 12 tahun untuk mengikuti pendidikan nonformal paket $\mathrm{A}$, paket $\mathrm{B}$, dan paket C.

\section{DAFTAR PUSTAKA}

Adioetomo SMS. 2005. Bonus Demografi menjelaskan hubungan antara pertumbuhan penduduk dengan pertumbuhan ekonomi [makalah dalam pengukuhan jabatan guru besar tetap Universitas Indonesia].
[BPS] Badan Pusat Statistik. 2015. Indeks Pembangunan Manusia 2014. Jakarta (ID). BPS.

[BPS] Badan Pusat Statistik. 2016. Penghitungan dan Analisis Kemiskinan Makro Indonesia 2016. Jakarta (ID). BPS.

[BPS] Badan Pusat Statistik. 2016. Indeks Pembangunan Manusia 2015. Jakarta (ID). BPS.

[BPS] Badan Pusat Statistik Provinsi Kalimantan Tengah.2015. Statistik Ketenagakerjaan Kalimantan Tengah Agustus 2014. Palangka Raya (ID). BPS.

[BPS] Badan Pusat Statistik Provinsi Kalimantan Tengah. berbagai tahun. Kalimantan Tengah dalam Angka. Palangka Raya (ID). BPS.

[BPS] Badan Pusat Statistik Provinsi Kalimantan Tengah. 2016. Laporan Perekonomian Kalimantan Tengah 2015. Palangka Raya (ID). BPS.

Damanhuri DS, Findi M. 2014. Masalah dan Kebijakan: Pembangunan Ekonomi Indonesia. Bogor (ID): IPB Press.

[DIKTI] Direktorat Jenderal Pendidikan Tinggi. 2016. Perguruan Tinggi yang ada di Provinsi Kalimantan Tengah. diakses dari http://forlap.dikti.go.id/perguruantinggi/search pada tanggal 11 Januari 2017.

Hamzah MZ, Risqiani R, Sofilda E. 2012. Human Development Quality and Its Problems In Indonesia. International Journal of Sustainable Developmen. 05:07.

Haughton J, Khandker SR. 2012. Pedoman tentang Kemiskinan dan Ketimpangan. Tim Penerjemah World Bank. Jakarta (ID) : Salemba Empat. Terjemahan dari: Handbook on Poverty and Inequality.

Juanda B, Junaidi. 20212. Ekonometrika Deret Waktu Teori dan Aplikasi. Bogor (ID): IPB Press.

Mankiw NG. 2007. Makroekonomi. Liza F, Nurmawan I, penerjemah. Edisi Keenam. Jakarta (ID); Erlangga. Terjemahan dari: Macroeconomics.

Mirza DS. 2012. Pengaruh Kemiskinan, Pertumbuhan Ekonomi dan Belanja Modal 
Terhadap Indeks Pembangunan Manusia di Jawa Tengah Tahun 2006-2009. Economics Development Analysis Journal. 1(1): 1-15.

Pratowo, NI. 2011. Analisis Faktor-Faktor yang Berpengaruh Terhadap Indeks Pembangunan Manusia. Jurnal Studi Ekonomi Indonesia: Surakarta.

Sa'diyah A. 2014. Analisis Faktor-Faktor yang Memengaruhi Indeks Pembangunan Manusia di Provinsi Nusa Tenggara Barat [Skripsi]. Bogor (ID). Institut Pertanian Bogor.

Salvatore D. 1994. Ekonomi Internasional. Edisi Ketiga. Jakarta (ID): Erlangga.

Sofilda E, Hamzah MZ, Sholeh AS. 2013. Human Development and Poverty in Papua Provincen (An Analysis of Simultaneous Approach on Panel Data Regresion). International Journal of Sustainable Development. 06:06.

Todaro MP, Smith SC. 2006. Pembangunan Ekonomi. Munandar H, AL Puji, penerjemah.
Edisi Kesembilan. Jakarta (ID): Erlangga. Terjemahan dari: Economic Development.

Trunajaya IP. 2015. Faktor-Faktor yang Mempengaruhi Indeks Pembangunan Manusia di Seluruh Provinsi Indonesia [Skripsi]. Bogor, Bogor (ID). Institut Pertanian Bogor.

[UNDP] United Nations of Development Program. 1990. Human Development Report 1990. NewYork (US). Oxford University Press.

[UNDP] United Nations of Development Program. 2015. Human Development Report 2015. New York (US). UNDP.

Widarjono A. 2005. Ekonometrika: Teori dan aplikasi untuk Ekonomi dan Bisnis. Yogyakarta (ID): Ekonisia.

Yuliati A. 2012. Analisis Faktor-Faktor yang Memengaruhi Indeks Pembangunan Indonesia di Wilayah Perbatasan Indonesia [Tesis]. Bogor (ID). Institut Pertanian Bogor. 